\title{
Activation of innovative activity in the manufacturing industry: regional aspect
}

\author{
Vitaly Makoveev ${ }^{1}$, and Evgeny Mazilov², Irina Akhmetova ${ }^{3}$ \\ ${ }^{1}$ Vologda state University \\ ${ }^{2}$ Vologda scientific center of the Russian Academy of Sciences \\ ${ }^{3}$ Kazan State Power Engineering University, str. Krasnoselskaya, 51, 420066, Kazan, Russia
}

\begin{abstract}
Sustainable long-term development of the energy sector is impossible without a developed manufacturing industry and especially machine-building enterprises. In this regard, the article based on the analysis of the works of domestic and foreign researchers developed and tested a method for assessing the level of development of innovation in the manufacturing industry, taking into account the volume of output, the degree of involvement of enterprises in the sector of innovation and labor productivity in the production of innovative products. An economic and mathematical model is constructed to determine the degree of influence of socio-economic factors on the level of development of innovative activities in the manufacturing industry.
\end{abstract}

\section{Introduction}

Sustainable long-term development of the energy sector is impossible without a developed manufacturing industry and especially machine-building enterprises.

The manufacturing industry is one of the drivers of innovative economy development, the main production of the most technologically complex and high-tech products with high added value is concentrated in this sector. On the one hand, the variety of technological processes concentrated on manufacturing enterprises makes this sector the main source of innovative products, goods and services, and on the other hand, it is the main consumer of a wide range of innovative developments.

It should be especially noted that the manufacturing industry makes a great contribution to the economic development of the country. In 2013, enterprises in this sector accounted for almost $40 \%$ of GDP. Social significance is emphasized by the fact that about $15 \%$ of the total number of people employed in the economy work in the manufacturing industry (table 1).

However, in the process of market transformations, the products of domestic manufacturing enterprises have become significantly inferior in competition in international markets. There is a steady increase in imports and a decrease in exports of products of enterprises in this sector. For example, during the period 2005-2013, the share of exports of manufacturing enterprises in the total volume of Russian exports decreased by 0.7 percentage points and amounted to in 2013. 16.6\% (in developed countries such as the United States, Germany, and Japan, the share of manufacturing exports in total exports is about $80-95 \%$ ). It should be especially noted that against the background of increased imports of machinery and equipment by $15 \%$ over the period from 1995 to 2013, their exports decreased by almost 2 times, thus the domestic industry becomes technologically dependent on foreign suppliers (table 2).

Such trends led to the fact that in 2012 the share of Russia in the total volume of world exports of machinery and equipment was only $0.26 \%$, while the United States $-9.1 \%$, Germany- $11.4 \%$, China- $16.6 \%$, and Japan- $8.2 \%$ [1].

The low competitiveness of products produced by the domestic processing complex is due to the weak level of innovation development. Despite the fact that manufacturing enterprises make a significant contribution (almost $72 \%$ in 2013) to the formation of the total volume of innovative products, the level of their innovation activity for the period 2005-2013. it did not exceed $13 \%$, and the share of innovative products in the total volume of shipped products $-12 \%$ (for comparison, in European countries the level of innovation activity of industrial enterprises is much higher, for example, in Finland it is $52.5 \%$, in Germany - $71.8 \%$, in France $40.1 \%)$. This indicates a low interest of manufacturing enterprises in innovative developments (table 3).

In this regard, an important issue is understanding the obstacles that arise in the development of innovative activities in the manufacturing industry. Knowing their specifics, it is possible to develop a set of measures to activate the process of creating and implementing innovations and create favorable conditions for the sustainable development of the national industrial complex. 
Table 1. Share of manufacturing industry in the Russian economy, \%.

\begin{tabular}{|l|c|c|c|c|c|c|}
\hline \multirow{2}{*}{ Indicator } & \multicolumn{3}{c|}{ Year } & \multirow{2}{*}{2013 to 2005 п.п. } \\
\cline { 2 - 7 } & 2005 & 2010 & 2011 & 2012 & 2013 & $-1,8$ \\
\hline In the gross regional product & 41,1 & 40,8 & 40,7 & 40,4 & 39,3 & $-0,5$ \\
\hline In the cost of fixed assets & 8,8 & 8,6 & 8,2 & 8,1 & 8,3 & $-0,7$ \\
\hline In the volume of exports & 17,3 & 16,4 & 16,3 & 16,4 & 16,6 & $-2,5$ \\
\hline In the number of employees & 17,2 & 15,2 & 15,2 & 15,0 & 14,7 & 4,3 \\
\hline In tax revenues to budgets of all levels & 13,8 & 17,5 & 17,4 & 18,0 & 18,1 & $-2,3$ \\
\hline In the volume of investments & 16,4 & 13,2 & 12,9 & 13,4 & 14,1 & \\
\hline Source: calculated by the author based on Rosstat data
\end{tabular}

Table 2. Commodity structure of exports and imports of the Russian Federation, \%.

\begin{tabular}{|l|c|c|c|c|c|c|}
\hline \multirow{2}{*}{ Group of products } & \multicolumn{3}{c|}{ Export } & \multicolumn{3}{c|}{ Import } \\
\cline { 2 - 7 } & 1995 & 2005 & 2013 & 1995 & 2005 & 2013 \\
\hline Machinery and equipment & 10,2 & 5,6 & 5,4 & 33,6 & 44,0 & 48,6 \\
\hline Metals, gemstones and things made of it & 26,7 & 16,8 & 10,5 & 8,5 & 7,7 & 7,1 \\
\hline Wood and pulp and paper products & 5,6 & 3,4 & 2,1 & 2,4 & 3,3 & 2,1 \\
\hline Chemical industry products, rubber & 10,0 & 6,0 & 5,8 & 10,9 & 16,5 & 15,8 \\
\hline Mineral products & 42,5 & 64,8 & 71,6 & 6,4 & 3,1 & 2,2 \\
\hline Food and agricultural raw materials & 1,8 & 1,9 & 3,1 & 28,1 & 17,7 & 13,6 \\
\hline Other goods & 3,2 & 7,1 & 1,5 & 10,1 & 7,7 & 10,6 \\
\hline Source: calculated by the author based on Rosstat data.
\end{tabular}

Table 3. Indicators reflecting the level of innovation development in the manufacturing industry of the Russian Federation

\begin{tabular}{|l|c|c|c|c|c|c|}
\hline \multicolumn{1}{|c|}{ Indicator } & \multicolumn{3}{c|}{ Year } & 2013 to 2005 \\
\cline { 2 - 6 } & 2005 & 2010 & 2011 & 2012 & 2013 & 1,0 \\
\hline Level of innovation activity of MI enterprises, \% & 10,9 & 11,3 & 11,6 & 12,0 & 11,9 & \\
\hline $\begin{array}{l}\text { MI contribution to the total volume of innovative } \\
\text { products, \% }\end{array}$ & 84,8 & 79,7 & 62,1 & 68,7 & 71,8 & $-13,0$ \\
\hline $\begin{array}{l}\text { Share of innovative products shipped by MI in the total } \\
\text { volume of goods shipped, works performed, services, \% }\end{array}$ & 7,0 & 6,7 & 6,8 & 9,6 & 11,6 & 4,6 \\
\hline $\begin{array}{l}\text { MI - manufacturing industry. } \\
\text { Source: calculated by the author based on Rosstat data. }\end{array}$ \\
\hline
\end{tabular}

To identify factors that hinder the development of innovation in the manufacturing industry, it is necessary to be able to assess the level of its development.

Currently, a large number of works are devoted to assessing the level of innovative development of countries and regions. Research in this area has started relatively recently, but a number of methodological approaches to solving this problem have already been developed. In particular, the issues of assessing the level of development of innovative activity are considered in the works of: I. Novikova, I. M. Bortnik, G. I. senchen, E. P. Amosenok, V. A. Bazhanov, L. S. Veseloy, A.V. Sokolov, V. N. Borisov, O. V. Pochukayeva, N. N. Volkova, E. Romanyuk, etc.[2, 3, 4, 5, 6, 7, 8, 9, 10, 11, $12,13,14,15,16,17]$.

It should be noted that most publications offer methods for assessing the innovative development of territories by aggregating individual indicators into integrated ones, while very little attention is paid to measuring the innovative development of the industrial complex, including manufacturing industries.

Analysis of the advantages and disadvantages of the above methods for assessing the innovative development of territories and sectors of the economy showed that none of the developments can be used to measure the level of development of innovation in the manufacturing industry of the region (table 4).

The problem with using some methods (for example, the method of N. N. Volkova, E. I. Romanyuk) is that not all the indicators proposed for evaluation can be obtained from available statistical sources. The criteria proposed in the methodology can only be obtained by conducting additional research and studying the accounting materials, which is quite difficult due to financial and time constraints. In addition, certain groups of indicators are assigned certain weights based on data from expert surveys, which, in our opinion, is quite controversial, since it has a subjective basis.

In the methodology of $\mathrm{V}$. N. Borisov and O. V. Pochukaeva, it is proposed to assess the level of development of innovative activity in industries based on aggregation of 2 indicators: the share of products of innovative-active enterprises and innovative products in the total production volume. However, the assessment of the presented indicators does not take into account the degree of involvement of manufacturing enterprises in innovation and labor productivity in the production of innovative products, which, in our opinion, is extremely important when evaluating the results of innovation in industries. 
Table 4. Characteristics of methods for assessing the innovative development of territories and sectors of the economy

\begin{tabular}{|c|c|c|c|c|c|}
\hline Methodology & 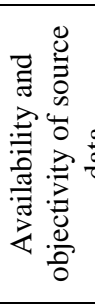 & 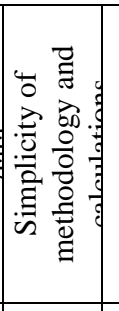 & 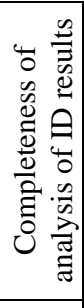 & 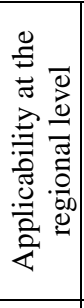 & 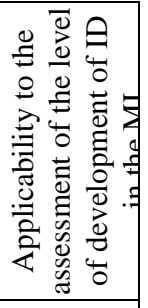 \\
\hline Factor analysis of the region's innovation potential (E. P. Amosenok, V. A. Bazhanov) & + & - & + & + & - \\
\hline Rating of regions by level of innovation development (A. B. Gusev) & +- & + & +- & + & - \\
\hline $\begin{array}{l}\text { Evaluation of the innovation system at the regional level (N. N. Volkova, R. I. } \\
\text { Romanyuk) }\end{array}$ & +- & + & +- & + & - \\
\hline $\begin{array}{l}\text { Methods of assessing the level of development of innovative processes in mechanical } \\
\text { engineering (V. N. Borisov, O. V. Pochukaeva) }\end{array}$ & + & + & - & + & +- \\
\hline Index of scientific and technical potential of the region (I. A. Kondakov) & + & + & + & + & - \\
\hline
\end{tabular}

In this regard, the relevance of this study is to develop a methodology for assessing the level of development of innovation in the manufacturing industry based on available data from regional and Federal statistics that do not require additional research, as well as to use this methodology to build ratings of regions by the level of development of innovation in the manufacturing industry.
Taking into account the specifics of the problem being solved, we have proposed a method for assessing the level of development of innovation in the manufacturing industry, which includes 5 consecutive stages (table 5).

To assess the level of development of innovation in the manufacturing industry, the following indicators were selected:

Table 5. Methodology for assessing the level of development of innovation in the manufacturing industry

\begin{tabular}{|c|c|}
\hline Stage name & Procedure \\
\hline $\begin{array}{l}\text { 1. Identification of parameters for } \\
\text { calculating the level of innovation } \\
\text { development in the manufacturing } \\
\text { industry (IDmi) }\end{array}$ & $\begin{array}{l}\text { Determination of a set of statistical indicators that characterize the degree of } \\
\text { development of innovative activity in manufacturing enterprises. }\end{array}$ \\
\hline $\begin{array}{l}\text { 2. Determination of standardized } \\
\text { coefficients for each observation unit } \\
\text { (territory) }\end{array}$ & $\begin{array}{l}\text { When calculating standardized coefficients, the maximum or minimum values for } \\
\text { each parameter were taken into account, depending on whether the parameter is } \\
\text { direct or inverse. } \\
\mathrm{IDmi}_{\mathrm{i}}=\frac{\mathrm{xi}-\mathrm{min}(\mathrm{xi})}{\Delta(\mathrm{xi})} \text { or IDmi }=\frac{\Delta(\mathrm{xi})}{\max (\mathrm{xi})-\mathrm{xi}} \text { (depending on whether } \\
\text { the initial indicator is direct or reverse), where XI is the initial values of indicators } \\
\text { for the I-th territory. }\end{array}$ \\
\hline $\begin{array}{l}\text { 3. Determination of an integral indicator } \\
\text { that characterizes the level of } \\
\text { development of innovative activity in the } \\
\text { manufacturing industry for each } \\
\text { observation unit (territory) }\end{array}$ & $\begin{array}{l}\text { Integral indicators were calculated using the following formula: } \\
\qquad \text { IDmi }=\sqrt{\frac{\sum_{j=1}^{n}(\text { IDmi i })^{2}}{n}} \\
\text { where IDmi } i \text { is the standardized coefficient for the } \mathrm{i} \text {-th territory, } \mathrm{n} \text { is the number of } \\
\text { indicators taken into account in the calculation. }\end{array}$ \\
\hline $\begin{array}{l}\text { 4. Defining the boundaries of intervals } \\
\text { and determining the observation units } \\
\text { (territories) that fall into each group. }\end{array}$ & $\begin{array}{l}\text { The interval of values of the integral indicator }[0 ; 1] \text { was divided into } 5 \text { groups with } \\
\text { the same interval value for each group. Since the distribution of observation units in } \\
\text { groups does not correspond to the Gauss distribution law (it is not normal), the } \\
\text { method of secondary rearrangement was applied with a certain proportion of } \\
\text { population units set for each group (1st and } 5 \text { th- } 15 \%, 3 \text { rd-30\%, 2nd and } 4 \text { th- } 20 \%) \text {. } \\
\text { 1. High (IDmi } \in(0,56 ; 0,71]) \text {; } \\
\text { 2. Above average (IDmi } \in(0,51 ; 0,56]) \text {; } \\
\text { 3. Average (IDmi } \in(0,42 ; 0,51]) ; \\
\text { 4. Below average (IDmi } \in(0,20 ; 0,42]) \text {; } \\
\text { 5. Low (IDmi } \in[0,0 ; 0,2]) ;\end{array}$ \\
\hline
\end{tabular}


Table 6. Ranking of constituent entities of the Russian Federation in terms of development of innovative activity in manufacturing industry

\begin{tabular}{|c|c|c|c|c|}
\hline \multirow{2}{*}{ Territory } & \multicolumn{2}{|c|}{$2006-2009$ years } & \multicolumn{2}{|c|}{$2010-2013$ years } \\
\hline & Index value & Rank & Index value & Rank \\
\hline Samara region & 0,707 & 1 & 0,692 & 1 \\
\hline Republic of Mordovia & 0,570 & 5 & 0,685 & 2 \\
\hline Moscow & 0,569 & 7 & 0,644 & 3 \\
\hline Lipetsk region & 0,523 & 10 & 0,637 & 4 \\
\hline Chuvash Republic & 0,518 & 13 & 0,622 & 5 \\
\hline Perm region & 0,672 & 2 & 0,613 & 6 \\
\hline Saint-Petersburg & 0,569 & 6 & 0,613 & 7 \\
\hline Nizhniy Novgorod region & 0,578 & 3 & 0,612 & 8 \\
\hline Ulyanovsk region & 0,572 & 4 & 0,598 & 9 \\
\hline Yaroslavl region & 0,503 & 19 & 0,574 & 10 \\
\hline \multicolumn{5}{|c|}{${ }$} \\
\hline Trans-Baikal Krai (Territory) & 0,231 & 67 & 0,162 & 71 \\
\hline Republic Of North Osetia-Alania & 0,212 & 68 & 0,153 & 72 \\
\hline Republic Of Sakha (Yakutia) & 0,098 & 75 & 0,128 & 73 \\
\hline Republic Of Tyva & 0,104 & 72 & 0,121 & 74 \\
\hline Jewish Autonomous region & 0,101 & 78 & 0,106 & 75 \\
\hline Chukotka Autonomous region & 0,092 & 76 & 0,103 & 76 \\
\hline Magadan region & 0,132 & 72 & 0,078 & 77 \\
\hline Republic of Ingushetia & 0,000 & 79 & 0,049 & 78 \\
\hline Chechen Republic & 0,000 & 80 & 0,009 & 79 \\
\hline Republic Of Kalmykia & 0,000 & 78 & 0,009 & 80 \\
\hline
\end{tabular}

1. the Share of innovative products shipped by enterprises of the processing complex in the total volume of products shipped (this indicator reflects the volume of innovative products produced by enterprises of the processing complex. The higher the value of this indicator, the more dynamic the diffusion of innovations is).

2. the Share of innovative products shipped by enterprises of the processing complex in the total volume of innovative products in the region (this indicator allows you to determine the contribution of enterprises of the processing complex to the formation of the total volume of innovative products created in the region).

3. the level of innovation activity of manufacturing enterprises (this indicator allows you to assess the degree of involvement of manufacturing enterprises in innovation).

4. the Volume of innovative products shipped by enterprises of the processing complex per employee (this indicator allows you to measure labor productivity in terms of production of innovative products).

The choice of these indicators is also due to the fact that they allow you to determine the scale of production forces in terms of production of innovative products, comprehensively measure the results of their innovation activities and conduct analytical comparisons with production and economic results.

Based on the developed methodology, an analysis was carried out for all subjects of the Russian Federation for the period 2006-2013. A high level of development of innovative activity in the manufacturing industry was observed in the regions and cities of the Central (Lipetsk and Yaroslavl regions, Moscow), Volga (Nizhny Novgorod, Samara and Ulyanovsk regions, the Republic of Mordovia, the Chuvash Republic and Perm Region) and North-Western (Saint Petersburg) Federal districts. Among the regions with the lowest level of development of innovative activity in manufacturing industry has entered the territory of the far East (Republic of Sakha (Yakutia), Jewish Autonomous region, Chukotka Autonomous Area and Magadan area), Siberian (TRANS-Baikal territory and the Republic of Tuva), South (Republic of Kalmykia) and North Caucasian (Chechen Republic and Republic Ingushetia and North Ossetia - Alania) Federal districts (table. 6).

To identify factors influencing the level of development of innovative activity in the manufacturing sector, the study formulated a list of 17 socio-economic indicators, which had the necessary statistical base and the possibility of its quantitative and qualitative assessment (table. 7).

The study of the relationship between the level of innovation development in the manufacturing industry and socio-economic factors was carried out on the basis of statistical factor and correlation-regression analysis for the period 2006-2013 for all subjects of the Russian Federation (640 observation points) $[18,19,20]$.

Based on the correlation analysis, it was found that 8 of the 17 selected indicators had a fairly close relationship with the level of development of innovative activity in the manufacturing industry. Statistical factor analysis allowed us to group these 8 indicators into three components: financial (f), human resources (HR) and production $(\mathrm{P})$.

The financial component included such indicators as: the share of expenditures on technological innovations of manufacturing enterprises in the total volume of expenditures on technological innovations; the share of 
Table 7. List of indicators for the assessment of the factors influencing the level of development of innovation activities in the manufacturing industry

\begin{tabular}{|c|c|c|}
\hline № & Index & $\begin{array}{c}\text { Unit of } \\
\text { measure }\end{array}$ \\
\hline 1. & The value of fixed assets of enterprises of the manufacturing sector in the calculation of one worker & $\begin{array}{l}\text { Thousands } \\
\text { of rub. }\end{array}$ \\
\hline 2 & the degree of depreciation of fixed assets of manufacturing industries & $\%$ \\
\hline 3 & $\begin{array}{l}\text { Fixed assets turnover ratio (the volume of products shipped by enterprises in the manufacturing sector } \\
\text { per ruble of fixed assets) }\end{array}$ & $\begin{array}{l}\text { Thousands } \\
\text { of rub. }\end{array}$ \\
\hline 4 & Index of production by type of economic activity " Manufacturing» & $\%$ \\
\hline 5 & Number of advanced production technologies used per 100 thousand of population & unit \\
\hline 6 & $\begin{array}{l}\text { Share of production of machinery and equipment in the total volume of products shipped by enterprises in } \\
\text { the manufacturing sector }\end{array}$ & $\%$ \\
\hline 7 & $\begin{array}{l}\text { Share of expenditures on technological innovations, manufacturing sector enterprises, in the total volume } \\
\text { of expenditures on technological innovations }\end{array}$ & $\%$ \\
\hline 8 & $\begin{array}{l}\text { Share of expenditures on technological innovations in the total volume of goods shipped, works } \\
\text { performed, and services provided by manufacturing enterprises }\end{array}$ & $\%$ \\
\hline 9 & Internal research and development expenditures to GRP & $\%$ \\
\hline 10 & Share of investments in fixed assets of manufacturing enterprises in GRP & $\%$ \\
\hline 11 & $\begin{array}{l}\text { Proportion of the average salary of employees of manufacturing enterprises to the average salary for the } \\
\text { regional economy }\end{array}$ & $\%$ \\
\hline 12 & Profitability of goods sold (works, services) shipped by enterprises of the processing complex & $\%$ \\
\hline 13 & Proportion of research and development personnel in the total economically active population & $\%$ \\
\hline 14 & Number of students of higher educational institutions per 10 thousands of population & people \\
\hline 15 & Share of people with higher education in the total number of people employed in the economy & $\%$ \\
\hline 16 & Number of postgraduates and doctoral students per 100 thousand & people \\
\hline 17 & Number of organizations performing research and development per 10,000 population & units \\
\hline
\end{tabular}

investments in fixed assets of manufacturing enterprises in the gross regional product; the ratio of the average salary of employees of manufacturing enterprises to the average salary for the regional economy.

The personnel component includes: the share of personnel engaged in research and development in the total number of economically active population; the number of issued protection documents for inventions and utility models (per 10 thousand population); the share of the population with higher education in the total number of employees in the economy; the number of organizations performing research and development (per 10 thousand population).

The production component includes an indicator that reflects the degree of depreciation of fixed assets in manufacturing.

Based on the correlation and regression analysis of the resulting indicator, which was used as an index reflecting the level of innovation development in the manufacturing industry (IDmi), and the selected components, the regression equation is obtained:

$$
\mathrm{IDmi}=0.39+0.12 * \mathrm{~F}+0.04 * \mathrm{HR}-0.05 * \mathrm{P}
$$

The quality of the obtained model is confirmed by significant coefficients of multiple correlation (0.72) and determination (0.52), as well as high values of the Fisher criterion (227.5).

The coefficients of the regression equation indicate that the level of innovation development in the manufacturing industry depends to a large extent on financial factors, which account for $27 \%$ of the variation (the share of personnel and production components accounts for $24 \%$ and $11 \%$, respectively).

The obtained mathematical dependence shows that the increase in the level of development of innovation activities in manufacturing can be achieved due to the growth of financial and human factors (with increasing values of the financial and staffing components by $1 \%$, index that reflects the level of development of innovative activity in the manufacturing sector increased by 0.12 and 0.04 , respectively), as well as reducing the negative production factors (reduction of value of components production by $1 \%$ increases the index that reflects the level of innovation development in the manufacturing industry by 0.05 ).

The results of the regression analysis correlate with the results of surveys of managers of manufacturing enterprises in the Vologda region, which were conducted annually from 2005 to 2013 by employees of ISERT RAS. For example, in 2013 among the main factors hindering the development of innovation in the manufacturing industry, enterprise managers note: lack of own funds (66\%), high cost of innovations (54\%), lack of financial support from the state $(50 \%)$, progressive depreciation of fixed assets (39\%), lack of qualified personnel $(30 \%)$ [1].

Thus, summarizing the obtained results, we can conclude that the increase in the financing of innovation activities, increasing the number of organizations and staff engaged in research and development, increase the wages of workers in the manufacturing sector, as well as inventive activity and education level of the population by reducing the degree of wear of fixed assets of 
manufacturing industries creates prerequisites for the intensification and development of innovative activities in the manufacturing industry. This confirms the significant role of socio-economic factors in the development of innovative activities in the manufacturing industry and the need to create conditions on the part of state authorities and management to stimulate the financing of research and development, the development of human resources and the modernization of the manufacturing industry.

In this regard, to increase the level of development of innovative activities in the manufacturing industry, the following measures should be implemented:

- providing tax incentives and subsidizing interest rates on loans to manufacturing enterprises that carry out innovative developments;

- use of a system of preferential taxation for enterprises that invest large amounts of money in promising scientific developments;

- a significant increase in the wages of workers employed in the manufacturing and research sectors;

- strengthening the regulation of prices and tariffs for products of natural monopolies that are suppliers of raw materials for manufacturing enterprises; implementation of a set of measures aimed at forming a regional order in order to reorient the industrial complex from imported goods to domestic ones;

- assistance to manufacturing enterprises in commercializing their developments.

\section{References}

1. V. N. Makoveev, E. S. Gubanova, Management of innovative activity in the manufacturing industry: regional aspect, 166 (itsed RAS, 2015)

2. V. N. Borisov, O. V. Pochukaeva, Modernization of the manufacturing industry of the Russian Federation on the basis of sustainable development of domestic engineering, Problems of forecasting. 2, 55-63 (2011).

3. I. M. Bortnik, G. I. Senchenya, N. N. Mikheeva et al., System of evaluation and monitoring of innovative development of regions of Russia, Innovations, 9, 48-61 (2012).

4. N. N. Volkova, E. I. Romanyuk, The level of development of the innovation system, and the specialization of regions of Russia, Questions of statistics, 9, 38-47 (2011).

5. E. P. Amosenok, V. A. Bazhanov, L. S. Veselaya, A.V. Sokolov, ed. by G. M. Mkrtchyan, V. A. Bazhanov, Mechanical engineering as a dominant in innovative processes, 156 (Publishing house of ieopp SB RAS, 2008).

6. I. Novikova, I., Disproportions of innovative development of Federal districts, Economist, 12, 4652 (2014).

7. E. A. Mazilov, K. A. Gulin, Organizational and economic mechanism of industrial complex management as a tool for regional economic development, Economic and social changes: facts, trends, forecast, 3, 71-84 (2015).

8. I. V. Kuzmin, State scientific and technical policy and results of innovative activity in the region, Problems of territory development, 2, 146-158 (2015).

9. K. A. Zumkin, I. A. Kondakov, Scientific and technical potential of the region: assessment of the state and prospects of development, 205 (Vologda: ISERT RAS, 2010).

10. P. V. Mikhailovsky, E. P. Konyukhovsky, Assessment of factors of economic growth of the machine-building industry, Proceedings of the Ural state University of Economics, 18(1), 53-60 (2007).

11. O. S. Mariev, I. V. Savin, Factors of innovative activity in Russian regions: modeling and empirical analysis, Economics of the region, 3, 235-245 (2010).

12. E. P. Naberezhnye Chelny, Econometric assessment of factors of innovative activity in Russian regions, Journal of economic theory, 1, 83-89 (2015).

13. V. A. Ilyin, E. S. Gubanova, K. A. Zumkin, I. A. Kondakov, G. V. Leonidova, S. V. Terebova, Trends and problems of regional development., Problems of formation of innovative economy, 2, $656 \mathrm{p}$.

14. S. V. Terebova, E. S. Gubanova, Activation of the innovation process in the region, 179, (Vologda: vnkts tsemi RAS, 2009).

15. A.D. Shmatko, A. I. Gradoboev, Development of a system of quantitative characteristics of the degree of innovation of enterprises, Economics and entrepreneurship, 6, 460-464 (2013).

16. R. Moreno, R. Paci, S. Usei, Spatial spillovers and innovation activity in European regions, Working Paper CRENoS, 10 (2003).

17. B. Tether, A. Tajar, The Organisational-Cooperation Mode of Innovation and its Prominence Amongst European Service Firms, Research Policy, 37(4), 720-739 (2008).

18. S. A. Ayvazyan, V. S. Mkhitaryan, Applied statistics. Fundamentals of econometrics. Vol. 1: probability Theory and applied statistics [Text]: textbook for universities: in 2 volumes, 656 (ISPR. M.: UNITY-DANA, 2001).

19. I. I. Eliseeva, Statistics. Workshop [Text]: textbook. the allowance for high schools, 483 (2011)

20. A. A. Khalafyan, Statistica 6. Statistical analysis of data [Text]: textbook. manual for universities, 528 (Binom-Press, 2010).

21. I. Akhmetova, A. Tyfetylov, A. Tamakchi, O. Derevianko, Z. Syed, Improving the competitiveness of automobile engineering enterprises by advancement the internal control over its indicators, International Journal of Civil Engineering and Technology 9(13), 1865-1876 (2018)

22. O. Sivash, D. Ushakov, and M. Ermilova, Investment Process Resource Provision in the 
Agricultural Sector, IOP Conference Series: Earth and Environmental Science, 272(3), 032118 (2019) doi:10.1088/1755-1315/272/3/032118 